\title{
Cytogenetics and immature embryo culture at Embrapa Trigo breeding program: transfer of disease resistance from related species by artificial resynthesis of hexaploid wheat (Triticum aestivum L. em. Thell)
}

\author{
Maria Irene Baggio de Moraes Fernandes ${ }^{l}$, Ana Christina A. Zanatta ${ }^{l}$, Ariano Moraes Prestes ${ }^{l}$, \\ Vanderlei da Rosa Caetano ${ }^{2}$, Amarilis Labes Barcellos ${ }^{1}$, Dilma Cristina Angra ${ }^{3}$ and Valesca Pandolfi ${ }^{I}$ \\ ${ }^{1}$ Embrapa Trigo, BR 285, km 174, Caixa Postal 451, 99001-970 Passo Fundo, RS, Brasil. \\ Send correspondence to M.I.B.M.F.E-mail:mirene@cnpt.embrapa.br \\ ${ }^{2}$ Embrapa, Clima Temperado, Pelotas, RS, Brasil. \\ ${ }^{3}$ CEFET, Pato Branco, PR, Brasil.
}

\begin{abstract}
Worldwide wheat (Triticum aestivum $\mathrm{L}$. em. Thell, $2 \mathrm{n}=6 \mathrm{X}=$ 42 , AABBDD) breeding programs aim to reorganize genotypes to achieve better yields, environmental adaptation and food quality. The necessary interdisciplinarity for breeding purposes requires an accurate choice of the most appropriate cellular and/or molecular strategies available to be integrated with agronomic approaches in order to overcome the genetic limitation of each cultivated species, at each agroecosystem. Cytogenetics has given a great contribution to wheat genetic studies and breeding, due to viability of chromosomal variants because of homoeology among genomes in this allohexaploid species and the genus Triticum. The level of development of cytogenetic techniques achieved over the last 60 years has set wheat apart from other cereal crops in terms of possibilities to introduce genetic material from other species. Cytogenetic approaches have been extensively used in chromosomal mapping and/or resistance gene transference from tribe Triticeae-related species. Monosomic analysis, entire chromosomes engineered through single additions and/or substitutions, reciprocal translocation through radiation or manipulation of homoeologous pairing, as well as synthesis of new amphiploids to allow homologous recombination by chiasmata evolved considerably since the past decades. The association of tissue culture and molecular biology techniques provides bread wheat breeding programs with a powerful set of biotechnological tools. However, knowledge on genetic system components, cytotaxonomical relationships, cytogenetic structure and evolutionary history of wheat species cannot be neglected. This information indicates the appropriate strategy to avoid isolation mechanisms in interspecific or intergeneric crosses, according to the genome constitution of the species the desired gene is to be transferred from. The development of amphiploids as "bridge" species is one of the available procedures to facilitate gene flow between wheat and related species. Since the environment at the center of origin of wheat in Southern Asia is quite different from subtropical environments, Brazilian breeding programs overcome more challenges to adapt wheat crop to biotic and abiotic stresses than some other countries. The germplasm bank of Embrapa Trigo has about 1000 registered entries of Triticum relatives, Aegilops, Secale and Agropyron species supplied from several germplasm banks distributed over the world which were multiplied and/or selected for naturally occurring or artificially inoculated fungal diseases. Since Aegilops
\end{abstract}

squarrosa L. entries showed very good performance, the genetic variability observed in this species was firstly exploited. It is reported here the strategy used for transferring useful genes from Ae. squarrosa $(\mathrm{DD}, 2 \mathrm{n}=14)$ : crossing with tetraploid species (AABB, $2 \mathrm{n}=28$ ), rescue and in vitro culture of immature embryos for regeneration of the trihaploid $(\mathrm{ABD}, 2 \mathrm{n}=21)$ hybrid, and colchicine treatment for genome duplication resulting in the artificial synthesis of hexaploid wheat lines (AABBDD, $2 n=42$ ). Results of 10,739 artificial pollinations involving 28 cross combinations amongst eight $T$. durum L., T. dicoccum and T. cartlicum tetraploid entries used as female parents and ten selected $A e$. squarrosa sources of resistance as male parents are presented here. Immature embryos from 18 cross combinations were recovered and cultured in vitro. Green plantlets from 13 combinations were regenerated. Fertile amphiploids were recovered only from crosses among entries of tetraploid $T$. durum and diploid $A e$. squarrosa. They originated 11 fertile synthetic amphiploid lines from seven different combinations. Useful stem and leaf rust as well as powdery mildew resistance for future use in breeding programs were obtained.

\section{INTRODUCTION}

The importance of wheat (Triticum aestivum $\mathrm{L}$. em. Thell $2 \mathrm{n}=6 \mathrm{x}=42$, AABBDD) as food crop comes primarily from the viscoelastic properties of its endosperm gluten proteins for bread production, representing the food basis for western civilization development. The tribe Triticeae contains three of the major cereals - barley, rye and wheat - being used by humankind since prehistoric times, as well as the first and unique man made cereal Triticale. Octoploid ( $2 \mathrm{n}=8 \mathrm{x}=56$, AABBDDRR) and hexaploid ( $2 \mathrm{n}$ $=6 \mathrm{x}=42$, AABBRR) triticale are obtained crossing hexaploid wheat and rye $(2 n=6 x=42$, AABBDD $x 2 n=2 x=$ $14, \mathrm{RR})$ or tetraploid wheat and rye $(2 \mathrm{n}=4 \mathrm{x}=28, \mathrm{AABB} x$ $2 \mathrm{n}=2 \mathrm{x}=14$, RR) (Gregory, 1987). Several other members of this tribe are also important as forage and pasture grasses (Miller, 1987).

Wheat domestication occurred in primitive farms of Southwestern Asia, at the "Fertile Crescent" of Mesopotamia, between 7.000 and 9.000 BC (Bell, 1987). Since 
the beginning of plant breeding about 200 years ago, quite impressive improvements in yield, bread making quality, plant architecture, and increased resistance to biotic and abiotic stresses were obtained. The total number of accessions in national and local gene banks around the world has been estimated in about 400.000 entries although there may be duplications (Poehlman and Sleper, 1996).

Worldwide wheat breeding programs aim to reorganize genotypes to achieve better yields, adaptation to different agroecosystems and food quality. Genetics is the central discipline of plant breeding, but not the unique one. The desired expression of the great majority of agronomic characteristics in cultivated plants depends on better genotypes as well as an appropriate management with the environment.

The progressive integration of classical and modern methodologies derived from several biological disciplines into plant breeding programs broadens the possibility of reorganizing the genomes of cultivated species.

From a pragmatical point of view, for crop improvement programs to supply the useful demand for useful genetic products it is necessary a deep understanding of the role of meiotic and breeding systems, which are the two main components of each cultivated species genetic system that define the nature, the extent and the release of genetic variability in plants (Lewis and John, 1965).

Therefore, the necessary interdisciplinarity to better achieve breeding purposes requires an accurate choice of available and more appropriate cellular and/or molecular strategies. It is also necessary to integrate them with agronomic approaches in order to overcome the genetic limitations for the cultivation of distinct species at different agroecosystems (MacKey, 1970).

Since the environmental conditions prevailing at the center of origin of wheat are quite different from subtropical agroecosystems, Brazilian breeding programs face additional challenges to adapt wheat crop as compared to some other countries. Several biotic and abiotic stresses are environmentally circumvented by soil correction, different planting dates, crop rotation systems, as well as biological and/or chemical control of pathogens.

Nevertheless, when plant breeders obtain a distinct level of genetic adaptation, the use of cultural practices and/or agrochemicals may be reduced, increasing the protection of the environment, animals and human health. Better yields may also mean, as pointed out by Dr. J.M. Valls, avoidance of agricultural utilization of unexploited natural ecosystems, leading to desired environmental preservation.

Related species are an important pool of genes for resistance to biotic and abiotic stresses (Sears, 1965; Riley and Kimber, 1966; Knott and Dvorak, 1976). However, the exploration of such useful genes in crop breeding is limited by several isolation mechanisms between species usually observed in interspecific or intergeneric crosses (Feldmann, 1976, 1977; MacKey, 1987).

Such genetic barriers may result in: 1) no fertiliza- tion at all, 2) hybrid inviability occurring at different stages of plant development, or 3) hybrid sterility. When hybrid sterility is caused only by lack of homologous chromosomes, new amphiploids may be easily obtained through genome duplication with colchicine.

Consequently, the knowledge of cytotaxonomical relationships, cytogenetic structure and evolutionary history of the species involved in the crosses indicate the most appropriate procedure necessary to avoid isolation mechanisms according to the genome constitution of the species presenting the gene to be transferred (Knott, 1989; Darlington, 1973).

At the same time, hybridization between species depends on several experimental and environmental variables that may be circumvented by crossing different genotypes, changing male and female parents, using other species as bridges, in vitro culturing immature embryos and cytologically selecting euploid and resistant plants in segregant progenies (Riley and Kimber, 1966).

Cytogenetics, as a discipline that deals with the mechanical basis of Mendelian inheritance, is of fundamental importance to wheat breeding programs. The great contribution of chromosomal engineering to the understanding of wheat genetics is due to the viability of aneuploid chromosomal variants and the discovery of the role of polyploidy in the evolution of Triticeae.

The determination of the basic chromosome number $(\mathrm{x}=7)$ in diploid, tetraploid and hexaploid wheats by Sakamura (1918) and extensive genome analysis by Kihara $(1919,1924)$, as reviewed by Lilienfeld (1951), was followed by the establishment of homoeology between genomes by Sears and Okamoto (1958) and Riley et al. (1958).

The use of colchicine for artificial duplication of genomes (Blakeslee, 1937) and the development of artificial media for embryo rescue and in vitro culture by Jenkins and Mochizuki (1957) were essential for the artificial increment of gene flow by introgression in the tribe Triticeae. The degeneration of hybrid endosperm would be overcome by embryo rescue and in vitro regeneration of hybrid plants, while sterility would be circumvented by treatment with colchicine for genome duplication.

In the past decades, classical cytogenetics and tissue culture techniques provided bread wheat breeding programs with a powerful set of biotechnological tools which nowadays are being complemented by molecular biology techniques.

The simultaneous use of in vitro culture of immature embryos, followed by cytological selection of plants with balanced euploid chromosome number and agronomic characteristics to be introduced in interespecific or intergeneric progenies, constitute the basis for transferring innumerous new genes of disease resistance (Sears, 1956, 1972; Riley and Kimber, 1966; Sharma and Knott, 1966; Cauderon, 1981; Gale and Miller, 1987; Worland et al., 1987). 
Cytogenetic information is also necessary when using haplodiploidization after intervarietal crosses for breeding purposes or for genetic studies, either via androgenesis (through in vitro anther or microspore culture) or via gymnogenesis (through in vitro immature embryos culture), to achieve complete homozigosity in only one generation (Moraes-Fernandes et al., 1991, 1999; Picard et al., 1994; Peters et al., 1999).

The impressive advances on cellular and molecular methodologies that are coming into widespread use in breeding programs are progressing more slowly in bread wheat, as occurred in the past with other genetic approaches, because of the peculiarities of the genetic system of $T$. aestivum (Day and Lupton, 1987).

The availability of newer molecular marker systems such as AFLP (amplified fragment length polymorphism) and microsatellites may increase precision and save time to achieve better levels of resistance to either biotic or abiotic stresses in wheat. AFLP and microsatellites are both PCR based and amenable to automation, permitting the simultaneous screening of dozen of loci and detection of higher levels of polymorphism than other systems (Fedak, 1998).

On celular biology, the microspore technique for androgenetic haplodiploidization, already available for canola and barley, is progressing in wheat (Kasha et al., 1998).

The research on plant transformation for disease resistance, primarily using antifungal proteins that act against the pathogens is still in inicial stages but presenting very promising preliminary results (Bushnell et al., 1998; Barcelo et al., 1998; Blechl and Anderson, 1998; Chibbar et al., 1998; Fry et al., 1998; Higgins et al., 1998).

As stated by Snape (1987), stresses is an area of genetic ignorance that in the future will be confidentially much reduced. Aneuploid methods and emerging molecular techniques will facilitate and add precision to genetic analysis of useful genes.

\section{BREAD WHEAT GENETIC SYSTEM}

Triticum aestivum $\mathrm{L}$. em. Thell $(2 \mathrm{n}=6 \mathrm{x}=42)$ is an autogamous alohexaploid species (AABBDD) that combines the genomes of three diploid ancestrals (Peterson, 1965). The donors of the $A$ and $D$ genomes, T. monococcum $(2 \mathrm{n}=14, \mathrm{AA})$ and Aegilops squarrosa $(2 \mathrm{n}=14, \mathrm{DD})$ were already clearly identified by genomic analysis (Morris and Sears, 1967).

The great amount of worldwide studies trying to clarify wheat origin and evolution during this century gave rise to several different taxonomic propositions for the genus Triticum and tribe Triticeae species nomenclature. According to different authors, many names may be used for the same species, as is the case of Ae. squarrosa and $T$. tauschii (Bowden, 1959; MacKey, 1970; Feldmann, 1976).

Experimental crosses between T. monococcum (AA) and Ae. squarrosa (DD) and bread wheat (AABBDD) re- sulted in pairing between the chromosomes of the diploid species and the hexaploid wheat at meiosis (7 II,14 I) in both AABD and ABDD hybrids. In the process of becoming an alohexaploid species, six of the seven A chromosomes of wheat genome are still fully homologous to $T$. monococcum, while the seven D chromosomes are fully homologous to Ae. squarrosa (Lilienfeld, 1951; Riley, 1965) (Figure 1).

However, the donor of the B genome is still controversial and believed to be extinct, very modified or not yet discovered. Many diploid-related species studied showed partial homology and chromosome pairing so far but not to the extent observed for the $\mathrm{A}$ and $\mathrm{D}$ genome donors. Ae. speltoides $(2 \mathrm{n}=14, \mathrm{BB}$ ?) is the species generally accepted as the probable donor of the B genome (Sarkar and Stebbins, 1956; Dvorak, 1972; Miller, 1987; Yan et al., 1998) albeit the conflicting results between genome analysis based on chromosome pairing and molecular data. Variation on restriction fragments of repeated nucleotide sequences (RNS) suggests that the B genome is indeed related to $A e$. speltoides (Dvorak, 1998).

\section{MAPPING CHROMOSOMES AND GENES IN WHEAT GENOME}

The discovery by Sears $(1939,1944)$ of a spontaneous haploid plant of "Chinese Spring" wheat cultivar was the beginning of the monumental work of chromosomal engineering in this species. Because of the buffering effect of polyploidy, viable descendents presenting wide range of chromosome number were obtained from the artificial pollination of ABD trihaploid plants by AABBDD $(2 n=$ 42) hexaploids.

Sears selected 21 phenotypically distinct monosomic plants $(2 n=41)$ that were assigned by Roman numerals from I to XXI and later by numbers and genome designating letters. The monosomics of each chromosome pair were identified by Sears $(1954,1958)$ based on their phenotype. Since the majority of wheat chromosomes is very similar in size and centromere position, the author distinguished them by phenotypic differences. Distinct banding patterns obtained from more recent studies make possible to identify specific chromosomes through cytological examination (Flavell et al., 1987) .

The use of monosomic series on chromosome mapping is based on somatic chromosome countings and cytological selection. In each of the 21 monosomic families $(2 n-1)$, the plants segregate giving rise to $2 n, 2 n-1$ and $2 n-2$ seeds. The $2 n-1$ plants need to be cytologically identified before pollination by the cultivar to be mapped and the Mendelian segregation pattern of the character is statistically tested (qui-square) in the $21 \mathrm{~F}_{2}$ progenies.

In those progenies presenting distorted Mendelian segregation, the missing chromosome is the critical one, where the genetic factor coding for the character is located. This method evolved to chromosomal engineering to con- 


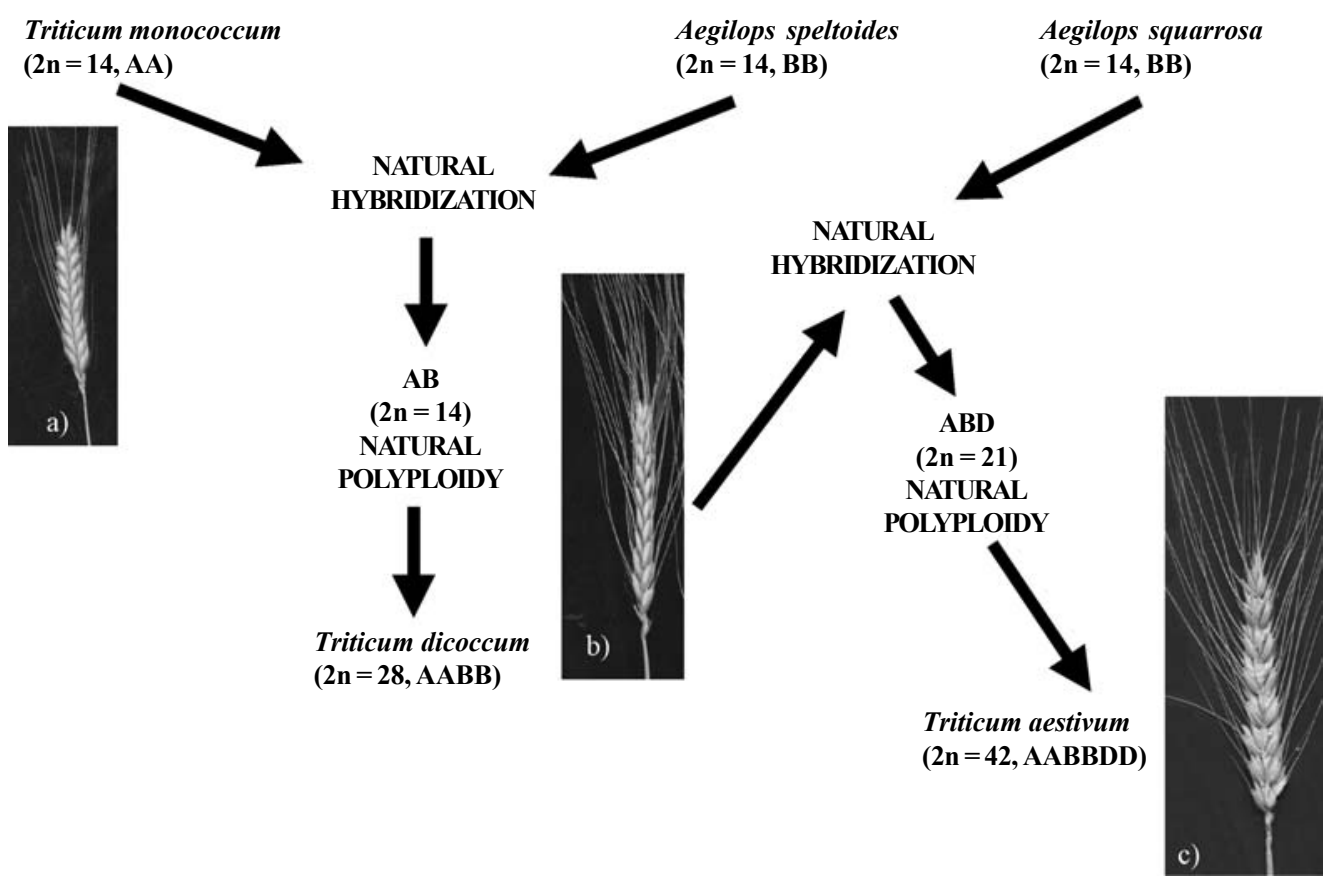

Figure 1 - Synoptic chart of cultivated wheats evolution: the diploid $(2 n=14, A A)$ forms of Triticum monococcum (a) were naturally pollinated by weed species, possible Aegilops speltoides $(2 \mathrm{n}=14$, BB?), in about 10,000 B.C. primitive farms. The subsequent genome duplication of hybrids by natural polyploidy gave rise to several wild and cultivated tetraploid species $(2 \mathrm{n}=28$, AABB) like Triticum dicoccum $(\mathbf{b})$ and Triticum durum (Figure 2a); again, the natural pollination of the tetraploid T. dicoccum (b) by another weed species, Aegilops squarrosa $(2 \mathrm{n}=14, \mathrm{DD})$ gave rise to the hexaploid $(2 \mathrm{n}=42$, AABBDD) species $(\mathbf{c})$.

struct addition and substitution lines to make genetic analysis of each individual chromosome and background genotypic effects possible (Kimber, 1977; Law et al., 1987).

The three wheat genomes (A, B, and D) were found to be partially genetically related. Many genes are duplicated or triplicated meaning four to six alleles at some loci instead of the characteristic two of diploid species (Riley et al., 1959).

Aneuploid studies proved the genomic homoeology among the majority of the chromosome pairs of each genome. Plants engineered to be nullisomic for one pair of chromosomes $(2 n-2)$ from one genome but tetrasomic $(2 n+2)$ for the equivalent pair on the other two genomes (nuli/tetrasomic) have the normal phenotype restored (Sears, 1966).

This genetic homoeology among genomes may distort the inheritance patterns of segregation since polysomy leads to more complex genetic studies and breeding methodologies (Sears, 1972). The occurrence of repeated loci suggest that the three wheat genomes possibly originated from a common ancestor.

Gill and Gill (1998) reported the construction of cytologically based physical maps of molecular markers for all 21 chromosomes of wheat in the past several years. Their work was based on a chromosome breakage system producing deletion stocks: from 436 deletion lines, 291 involving all 21 chromosomes were selected to map 384 markers. Ten different libraries of various Triticeae spe- cies were used to detect 908 loci. Because gene collinearity is conserved among A-, B- and D-genome homoeologous chromosomes, with few exceptions, consensus physical maps for the basic seven chromosome groups could be constructed, revealing that wheat genes are present in clusters interspersed by blocks of repetitive sequences visualized as regions of low gene density.

In spite of the genomic homoeology, usually chromosome pairing in wheat is regular, forming 21 pairs at meiosis. The regular pairing is a basic requirement to fertility, genetic stability and varietal uniformity in self-pollinated crops like bread wheat that has the seed as economic product (Riley and Law, 1965).

Chromosome pairing restrict to homologous chromosomes is guaranteed by a gene factor $(P h l)$ located on the 5B chromosome (Sears and Okamoto, 1958; Riley et al. 1958). When the long arm of the $5 \mathrm{~B}$ chromosome is absent, homoeologous pairing between chromosomes of the three genomes is possible and homoeologous translocations may occur. This gives the possibility of recombining chromosomes of wheat and other members of the tribe Triticeae.

Recently, Aragón-Alcaide et al. $(1996,1997)$ have reported the isolation of a DNA sequence (CCS1) specific to the centromere of chromosomes of cereals and other Triticeae grasses. The results obtained in the hybridization experiment suggest the existence of a structural difference between the centromeres of Phl-present and Phl-defficient genotypes (Miller et al., 1998). 


\section{CYTOGENETICS AND EVOLUTION: STRATEGIES FOR GENE TRANSFERENCE FROM RELATED SPECIES TO WHEAT}

Several useful cytogenetic strategies were developed to manipulate the chromosomes of part or the whole genome of a species for the improvement of bread wheat.

Many useful genes from wild species are available to be used in breeding programs as source of genes for disease resistance applying different chromosomal engineering techniques involving backcrosses, "bridges" species and selection of cytological as well as desired agronomic characteristics (Knott and Dvorak, 1976; Stalker, 1980; Dhalival et al., 1986; Gale and Miller, 1987).

The transfer of alien genes depends on the passage of a piece of chromosome from the donor species to the recipient species, which have to be as small as possible in order to avoid transferring undesirable characteristics. Obviously the transference will be easier if the donor species have chromosomes fully homologous to bread wheat, allowing the occurrence of crossing over and genetic recombination via chiasmata.

Riley and Kimber (1966) reviewed the possibility of transferring genes from related species to bread wheat by evaluating artificial amphiploids and chromosomal addition and substitution lines as well as translocated chromosomal segments. They concluded that, instead of trying to create new species of cereals like Triticale, it would be more useful to transfer the minimum alien variation into cultivated crops in order to avoid genetic unbalance in genomes that required so many generations to be adjusted by natural selection. They stated that Triticale is the only artificial amphiploid being used in agriculture.

After McFadden and Sears $(1944,1946)$ resynthesized a hexaploid wheat, the wide development of new amphiploids has been possible if treating the haploid hybrid with colchicine after artificial hybridization for the duplication of the genomes. Gene flow is thus possible using the artificial amphiploid as a "bridge species" because of the obvious better crossing compatibility of hexaploid wheat with species of the same or more similar ploidy levels.

The transference of genes involving small chromosomal segments may occur via chiasmata if there is genome homology between wheat (the receptor genome) and the species the gene(s) is(are) being transferred from (the donator genome). However, irradiation or manipulation of the 5B system to induce chromosomal breaks is indicated when the transference is made from homoeologous or nonhomoeologous species through reciprocal translocations. In this case, it is necessary to build up specific chromosomal additions or substitution lines carrying the resistance gene(s) (Riley and Kimber, 1966).

The characteristic triplication of bread wheat genetic material facilitates gene transference between related species since the effects of deleterious genes present on an alien chromosome substitution from one genome is masked by the presence of duplicated genes on the other two genomes.

Besides, the hexaploid plant can tolerate loss or addition of all chromosomes or segments of chromosomes without drastic effects on its viability. These factors, together with the level of development of aneuploid cytogenetic techniques achieved over the last 60 years, have set wheat apart from other cereals in terms of the possibilities for the introduction of genetic material from related species (Gale and Miller, 1987).

Nowadays, transgenesis emerges as a very promising tool for the manipulation of genes more distantly related and also for cloning and transferring genes from other Triticeae species. Indeed transgenesis will provide a wider and easier profit for wheat breeding programs in the near future, but cytogenetics knowledge and training will most certainly continue to be necessary.

\section{HOMOLOGOUS AND HOMOEOLOGOUS WHEAT-RELATED SPECIES}

It is obviously easier to use the diploids T. monococcum (AA), Aegilops squarrosa (DD), and the tetraploids T. turgidum, T. durum and T. dicoccum (AABB) to transfer genes into bread wheat because of the homology between their chromosomes and the chromosomes of the cultivated hexaploid wheat.

If a resistance trait is identified in $T$. monococcum $(2 \mathrm{n}=14, \mathrm{AA})$, it is mostly indicated to use the tetraploid species $(2 \mathrm{n}=28, \mathrm{AABB})$ as a bridge and backcross the triploid hybrids (AAB) to the tetraploid (AAB x AABB) (see Kerber and Dyck, 1973).

Before backcrossing, the euploids with $2 \mathrm{n}=28$ chromosomes and expressing the characteristic being transferred have to be selected at each generation. Similar procedure is recommended for the transference of genes from the tetraploid to the hexaploid level (AABB x AABBDD).

If the resistance trait is identified in Aegilops squarrosa $(2 \mathrm{n}=14$; DD), the transference may be done by crossing Ae. squarrosa with a tetraploid species (AABB $\mathrm{x}$ $\mathrm{DD})$. The $\mathrm{ABD}$ haploid embryos need to be in vitro cultured due to in situ endosperm degeneration.

The artificial resynthesis of fully homozygous hexaploid wheat carrying the desired gene from the $\mathrm{D}$ genome is accomplished by the duplication of the genomes with colchicine. The new synthetic bread wheat may be used directly in different breeding programs without any additional special procedure (Kerber and Dyck, 1969).

Useful genes from other species of the tribe Triticeae (Aegilops, Haynaldia, Agropyron, Secale and Hordeum) that normally do not pair with hexaploid wheat chromosomes are more difficult to transfer into bread wheat. The chromosomal engineering methodology may be very sophisticated depending on the genetic system of each species (Knott, 1961). 
The classical models are 1) the transference of rust resistance from Ae. umbelullata using radiation to induce translocation that originated the hexaploid wheat line named transfer (Sears, 1956), and 2) the transference of resistance to yellow rust from Ae. comosa to a line named compair through the manipulation of the $5 \mathrm{~B}$ system using a chromosome addition line crossed to Ae. speltoides that has the same pairing gene (Riley et al., 1968).

Innumerous studies on meiotic pairing of intergeneric hybrids indicate that homoeology is very common between other genus of the tribe Triticeae (Cauderon, 1981). Molecular studies indicating collinearity of distantly related species confirm the observations of homoeologous chromosome pairing between Triticeae genomes (Gill and Gill, 1998).

\section{LOOKING FOR GENETIC VARIABILITY TO DISEASE RESISTANCE IN WHEAT-RELATED SPECIES AT EMBRAPA TRIGO}

The main challenges, regarding stresses, faced by bread wheat breeders in southern Brazil are: 1) to overcome toxic levels of aluminum and manganese in the soil; 2) high variability within the fungi causing stem and leaf rust diseases introducing new races almost every year; 3 ) severe epidemics of necrotrophic diseases caused by a complex of pathogens, mainly those inducing leaf spots, roots, and head diseases; 4) prolonged rainy and cloudy days causing poor soil drainage and light stresses that may favor the attack of fungi; 5) strong winds during spring, and 6) drastic climatic fluctuation at flowering time causing male sterility, with frequent temperature drops of about $20^{\circ} \mathrm{C}$ in less than $24 \mathrm{~h}$ that may often be followed by severe frosts (Caetano, 1988; Moraes-Fernandes et al., 1991).

Some of these events may be controlled by resistance conferred by genes existing in local varieties or by soil management as for aluminum toxicity. However, water logging and light stress cannot be controlled by man.

Depending on the year, wheat losses due to diseases vary from 8 to $40 \%$ (Luz, 1984; Picinini et al., 1993). Brazilian wheat cultivars are worldwide considered to have a high level of resistance to several diseases. Nevertheless, this resistance may not be enough to overcome severe epidemics that occur in some extremely variable winters in southern Brazil, as well as new races of rust fungus.

Therefore the genetic variability available to be explored by wheat breeding programs may be amplified by new genes originated from wild species (Moraes-Fernandes, 1990).

The first access of wild species were introduced with the assistance and kindness of Dr. Eric Kerber, from the Winnipeg Experimental Station, Canada, who supplied Embrapa Trigo, in Passo Fundo, RS, Brazil, with about 200 samples of his own collection of wild species, mainly Aegilops squarrosa, and technical assistance for the project on wide crosses started in 1979 (Moraes-Fernandes et al., 1980).
New entries were obtained in 1985 from several regions of the world presenting winter environmental conditions similar to southern Brazil (Moraes-Fernandes et al., 1988). The purpose of these introductions was to amplify the possibilities of finding better genes for resistance to diseases occurring in southern Brazil.

Up to now the germplasm bank of Embrapa Trigo has about 1000 registered entries belonging to different species from several genus such as Agropyron, Aegilops, Hordeum, Secale and Triticum.

Seeds of new introductions were increased locally. However, high levels of pollen and seed sterility were observed in many entries of the species Triticum monococcum (AA, $2 n=14$ ) whenever typical southern Brazilian winter drastic temperature oscillations occurred.

On the other hand, entries of Ae. squarrosa $(2 \mathrm{n}=$ 14; DD) developed very well in Passo Fundo and did not show pollen or seed sterility. Besides that, according to Dr. Eric Kerber's personal observation, the size of $A e$. squarrosa spikes produced here was more than twice the size of heads from the same entries grown in Canada.

T. monococcum develops better in Canada than here, probably due to less environmental variation.

The presumed donor of the $\mathrm{B}$ genome, Ae. speltoides $(2 \mathrm{n}=14, \mathrm{BB}$ ?), developed very badly under Passo Fundo environmental conditions. Hence seeds had to be multiplied in growth chamber with artificially controlled environment.

These observations indicated that the $\mathrm{A}$ and $\mathrm{B}$ genomes may be less ecologically adapted to southern Brazil than the $\mathrm{D}$ genome. It was already suggested that the addition of the $\mathrm{D}$ genome led to an increased adaptation of hexaploid wheat to cooler, more temperate climates of central Asia and Europe or Brazil but much more studies in this line of research should be done.

The monosomic analysis of three worldwide important genes found in Brazilian germplasm performed at Embrapa Trigo showed that the gene for resistance to aluminum toxicity identified in the Brazilian wheat cultivar BH 1146 is located on chromosome 4D (Lagos et al., 1991) and the two genes for leaf rust adult-plant resistance identified in the Brazilian wheat cultivar Toropi (Barcellos et al., 2000) are located on chromosomes $1 \mathrm{~A}$ and 4D (Brammer et al., 1998). This is only another example of the innumerous interesting new cytogenetic areas that need to be enriched with more research. Reide and Anderson (1996) identified the chromosome arm carrying the gene for aluminum resistance in $\mathrm{BH} 1146$ wheat.

Intergeneric crosses were made between selected Agropyron elongatum ( $=$ Thinopyron ponticum, $2 \mathrm{n}=10 \mathrm{x}$ $=70$ ) entries and susceptible local wheat cultivars at Embrapa Trigo since 1988. Rescued immature embryos were cultured in vitro and the developed plants were backcrossed to wheat and latter on screened for disease resistance (Angra, 1995).

The haplodiploidization of selected progenies through 
somatic elimination of pollen donor genome by maize pollination and colchicine treatment is a routine procedure being used at Embrapa Trigo to transfer non-homologous chromosomal segments into local cultivars (Gouvea et al., 1997; Angra et al., 1999).

Since Ae. squarrosa entries presented very good results regarding disease resistance when evaluated at Embrapa Trigo, it was decided to start exploiting the genetic variability observed in this species (Moraes-Fernandes et al., 1980; Prestes et al., 1994). It is reported here the strategy used for transferring useful genes from $A e$. squarrosa $\mathrm{L}(2 \mathrm{n}=14, \mathrm{DD})$ by crossing it with tetraploid species $(2 n=28, A A B B)$ to artificially synthesize hexaploid lines of bread wheat.

\section{MATERIAL AND METHODS}

Pure lines of Ae. squarrosa L. entries kindly supplied by Dr. Eric Kerber were multiplied and stored at the germplasm bank of Embrapa Trigo. Those lines having winter or unknown growth habit were vernalized for 8 weeks at $3^{\circ} \mathrm{C}$ and cultivated in greenhouse.

The crosses, presented in Table I, were made by emasculating the female plants when pollen grains in the anthers were immature (Figure 2). In order to increase the probability of successful fertilization, the pollination was done several times before and after the ovary could be seen plumulous, an indication of receptiveness.

The flowers were daily observed to identify developing embryos. Best results were obtained in growth chamber than under greenhouse conditions because temperature and humidity control increases the survival rate of hybrid embryos.

Embryo rescue for in vitro culture was made 14 to 18 days after the pollination of the flowers to avoid starting endosperm degeneration. Roots of in vitro-regenerated green plantlets were pre-treated for chromosome counting.

After acclimatized in growing chamber, the plants were treated with $0.025 \%$ colchicine (Figure 3 ). The duplicated tillers were fertile while those remaining haploids were sterile. The seeds of the new fully homozygous duplicated genotypes were then multiplied for phytopathological tests.

\section{RESULTS}

Results of the crosses between Ae. squarrosa (DD) entries selected for resistance to diseases and the tetraploid "bridge" species (AABB) are shown in Table I.

A total of 10.739 artificial pollinations were performed in 28 cross combinations among eight $T$. durum L., T. dicoccum, and T. carthlicum tetraploid entries, used as female parents $(2 \mathrm{n}=28, \mathrm{AABB})$ and ten selected $A e$. squarrosa sources of resistance, used as male parents $(2 \mathrm{n}$ $=14 ; \mathrm{DD})$.

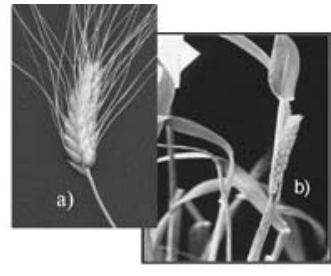

Triticum durum, $2 \mathrm{n}=28, \mathrm{AABB}$
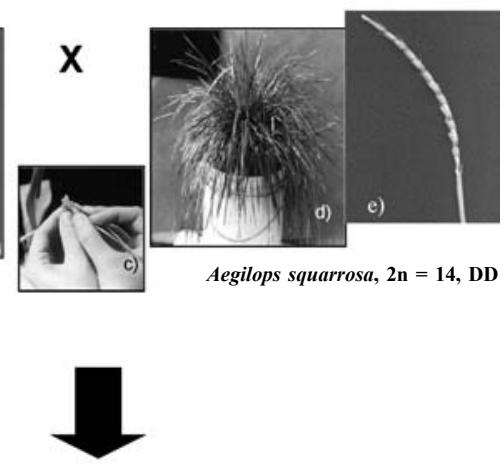

ABD, 2n $=21$
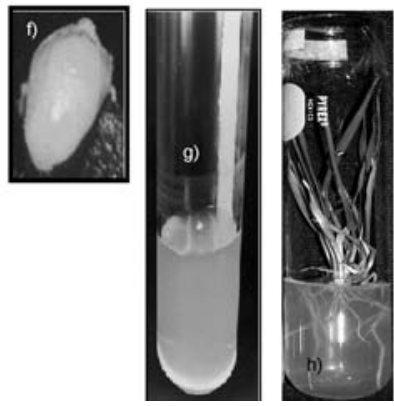

Figure 2 - For the experimental resynthesis of hexaploid wheat, a tetraploid species, Triticum durum, $2 \mathrm{n}=28$, AABB (a), is emasculated (b and $\mathbf{c}$ ), and pollinated by Aegilops squarrosa, $2 \mathrm{n}=14$, DD (d,e). The hybrid embryo, $2 \mathrm{n}$ $=21, \mathrm{ABD}$ needs to be rescued $(\mathbf{f}, \mathbf{g})$ for green plantlets regeneration $(\mathbf{h})$ and genome duplication by colchine treatment (Figure 3 ).

Immature embryos belonging to 18 cross combinations were rescued and cultured in vitro and green plantlets from 13 combinations were regenerated.

The frequency of successful fertilization is indicated by the number of grains developed, from which immature embryos were rescued. The frequency of grains formed varied from zero to a maximum of $19.0 \%$, observed in 1983 , in the cross $T$. dicoccum NE 22860/Ae. squarrosa NE 29431.

The highest frequency of in vitro green plantlets regeneration as well as the number of seeds from fertile plants harvested after colchicine treatment was observed in the cross T. durum NE 44665/Ae. squarrosa NE 29341. These results demonstrate the importance of trying several distinct genotypes as "bridges". The most resistant entries of Ae. squarrosa, NE 20211 and NE 20221, were respectively involved in 8 and 6 different cross combinations before be found one compatible in 1983. Among the 8 tetraploids used only the T. durum NE 22912 showed the desired compatibility.

In 1984, crosses using Ae. squarrosa as female parent resulted in better levels of successful fertilization and in vitro green plantlets regeneration. Nevertheless, no fertility was achieved after colchicine treatment since all plants died before tillering (Table II).

After colchicine treatment, fertile amphiploids were 

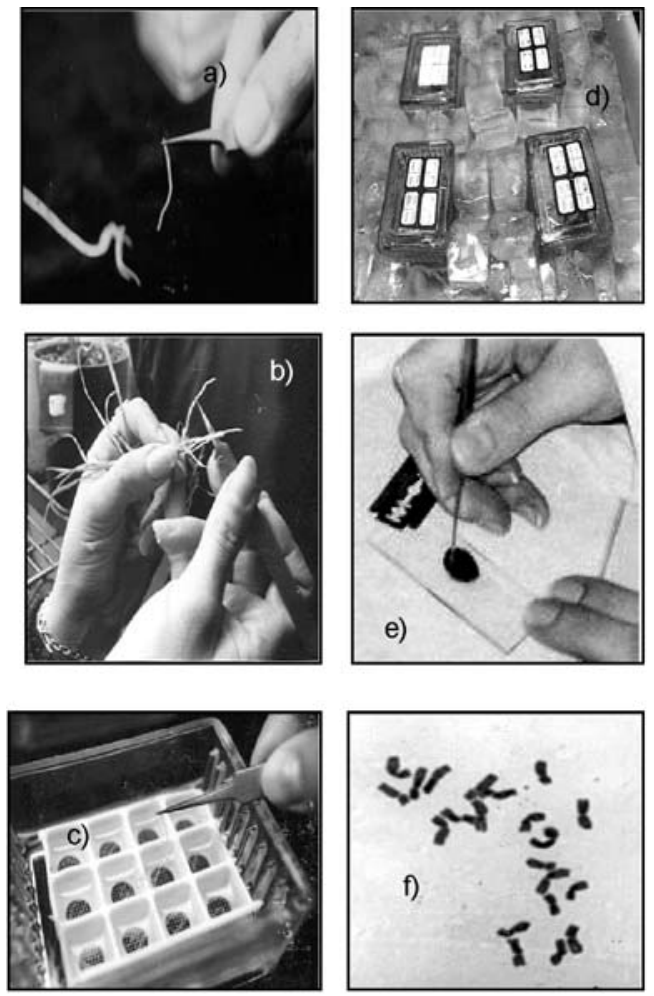
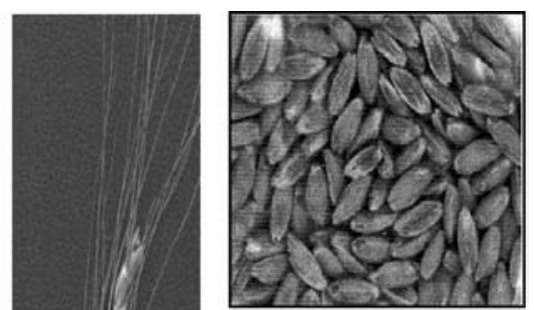

i)

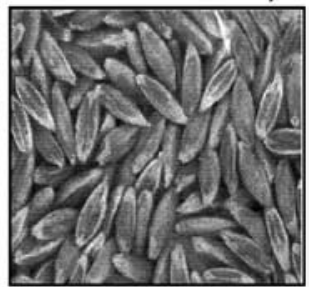

j)

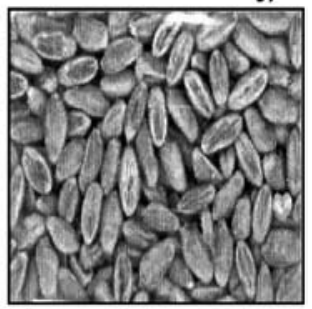

k)

Figure 3 - After root tips ice pre-treatment (a,b,c,d), chromosome counting confirms sucessful hybridization (e,f). The new tillers that will develop after colchicine treatment $(\mathbf{g})$, will present genomes duplication and consequently, fertility is restaured $(\mathbf{h})$. The new fully homozygous hexaploid lines, $2 \mathrm{n}=42$, AABBDD obtained $(\mathbf{i}, \mathbf{j}, \mathbf{k})$, may now be used to transfer the resistance genes either from $T$. durum or Ae. squarrosa to susceptible cultivars, by usual crossing procedures of conventional breeding programs without any other special procedure. Seeds of three new synthetic hexaploid lines obtained at Embrapa Trigo (Table I), PF 804001, PF 844004 and PF 844006 are show in i,j and $\mathrm{k}$.

obtained only from the crosses between the tetraploid $T$. durum and the diploid Ae. squarrosa, giving rise to 11 fertile synthetic lines from seven different cross combinations.

The Brazilian synthetic hexaploid wheat lines available to breeders since 1985 are presented in Table III.

The results of stem rust reaction of synthetic lines evaluated by E.T. Coelho for the six most important races occurring in southern Brazil in 1986 demonstrate that PF 804001, PF 804002, PF 834001, PF 844002, PF 844004, PF 844005, PF 844007 and PF 844008 showed better levels of resistance to stem rust races $G 11, G 15, G 18, G 20$, G23 and G24 than Sr33, the known gene transferred from Ae. squarrosa. Since both parents were resistant to these stem rust races, the synthetic hexaploids may have genes from both T. durum and Ae. squarrosa that can be explored by breeders in their research programs (Moraes-Fernandes et al., 1990).

The hexaploid synthetic line PF 834001 was also moderately resistant to powdery mildew, as evaluated by W.I. Linhares. The crosses, embryo culture and chromosome counting to obtain this synthetic hexaploid line were made by S.R. Antoniolli (Moraes-Fernandes et al., 1990). The progenitor Ae. squarrosa NE 20342 was immune to powdery mildew and $T$. durum NE 22912 was resistant. Hence, the expression of resistance and immunity of both parents was partially inhibited in the new genetic substract, as reported by Harvey et al. (1980). Kerber and Green (1980) observed that resistance to rust was suppressed in some synthetic lines.

The synthetics PF 844004 and PF 844005 derived from Ae. squarrosa NE 20211 were resistant to all important races of leaf rust, except race $\mathrm{B} 32$ and showed variation for race B26, according to the evaluation performed by A.L. Barcellos. The level of resistance to some races was better than that presented by $L r 21$, which is also derived from Ae. squarrosa.

\section{CONCLUDING REMARKS}

The alopolyploid nature of wheat and the extensive knowledge of its genome relationships provide plant breeders with a rare opportunity to exploit variation available in alien genera for crop improvement.

Nevertheless experiments on chromosome manipulation to transfer genes between species depend on the evaluation and correct identification of suitable characteristics to be transferred into bread wheat. 
Table I - Results of crosses between tetraploid species (AABB) and Aegilops squarrosa (DD).

\begin{tabular}{|c|c|c|c|c|c|c|c|c|}
\hline $\begin{array}{l}\text { Female parent } \\
\text { (AABB) }\end{array}$ & $\begin{array}{l}\text { Male parent } \\
\text { (DD) }\end{array}$ & $\begin{array}{c}\text { Flowers } \\
\text { pollinated }\end{array}$ & $\begin{array}{c}\text { Grains } \\
\text { formed }(\%)\end{array}$ & $\begin{array}{l}\text { Embryos } \\
\text { rescued }\end{array}$ & & $\begin{array}{l}\text { Green } \\
\text { plantlets }\end{array}$ & $\begin{array}{r}\text { Fertile plan } \\
\text { after }\end{array}$ & $\begin{array}{l}\text { ats recovered } \\
\text { olchicine }\end{array}$ \\
\hline \multicolumn{9}{|l|}{1980} \\
\hline T. dicoccum 22860 & Ae. squarrosa 29445 & 96 & 2.1 & 02 & & & & \\
\hline T. durum 22909 & Ae. squarrosa 29229-C & 544 & 0.7 & 04 & 04 & & 04 & \\
\hline T. durum 22912 & Ae. squarrosa 20229-C & 256 & 0.0 & & & & & \\
\hline T. durum 22909 & Ae. squarrosa 29445 & 244 & 1.2 & 03 & 00 & & 00 & \\
\hline \multirow[t]{2}{*}{ T. durum 22912} & Ae. squarrosa 29445 & 448 & 0.4 & 02 & 00 & & 00 & \\
\hline & & 1,780 & 0.7 & 12 & 4 & $(33.3 \%)$ & 04 & $(100.0 \%)$ \\
\hline \multicolumn{9}{|l|}{1981} \\
\hline T. dicoccum 22844 & Ae. squarrosa 29339 & 648 & 0.2 & 01 & 00 & & & \\
\hline T. dicoccum 22844 & Ae. squarrosa 20211-Y & 522 & 0.1 & 05 & 04 & & 00 & \\
\hline T. dicoccum 22844 & Ae. squarrosa 20229-a & 124 & 3.2 & 04 & 04 & & 00 & \\
\hline T. dicoccum 22844 & Ae. squarrosa 20229-b & 238 & 1.3 & 03 & 03 & & 00 & \\
\hline T. dicoccum 22844 & Ae. squarrosa 20221 & 100 & 0.0 & & & & & \\
\hline T. carthilicum 20141 & Ae. squarrosa 20229-b & 116 & 0.0 & & & & & \\
\hline \multirow[t]{2}{*}{ T. carthilicum 20141} & Ae. squarrosa 20291 & 16 & 0.0 & & & & 00 & \\
\hline & & 1,907 & 2.0 & 38 & 11 & (28.9) & & $0.0 \%(* *)$ \\
\hline \multicolumn{9}{|l|}{1982} \\
\hline T. durum 22912 & Ae. squarrosa 29342 & 2,110 & 2.5 & 53 & 38 & & 38 & \\
\hline T. durum 22912 & Ae. squarrosa 29338 & 87 & 0.0 & & & & & \\
\hline \multirow[t]{2}{*}{ T. durum 22912} & Ae. squarrosa 20221 & 90 & 0.0 & & & & & \\
\hline & & 2,287 & 2.3 & 53 & 38 & $(71.7 \%)$ & 38 & $(86.8 \%)$ \\
\hline \multicolumn{9}{|l|}{1983} \\
\hline T. durum 44665 & Ae. squarrosa 20211-C & 332 & 0.0 & & & & & \\
\hline T. durum 44665 & Ae. squarrosa $20211-\mathrm{Y}$ & 62 & 0.0 & & & & & \\
\hline T. durum 44665 & Ae. squarrosa 29338 & 144 & 0.0 & & & & & \\
\hline T. durum 44665 & Ae. squarrosa 29341 & 617 & 9.4 & 58 & 14 & & 14 & \\
\hline T. durum 44665 & Ae. squarrosa 29381 & 456 & 0.0 & & & & & \\
\hline T. durum 22912 & Ae. squarrosa 20211-C & 108 & 6.5 & 07 & 06 & & 06 & \\
\hline T. durum 22912 & Ae. squarrosa 20211-Y & 200 & 5.5 & 11 & 05 & & 05 & \\
\hline T. durum 22912 & Ae. squarrosa 29381 & 114 & 1.0 & 01 & 01 & & 00 & \\
\hline T. dicoccum 22860 & Ae. squarrosa 20211-C & 50 & 2.0 & 01 & 01 & & 00 & \\
\hline T. dicoccum 22860 & Ae. squarrosa 20211-Y & 158 & 0.6 & 01 & 01 & & 00 & \\
\hline T. dicoccum 22860 & Ae. squarrosa 20221-I & 266 & 1.5 & 04 & 02 & & 00 & \\
\hline T. dicoccum 22860 & Ae. squarrosa 29338 & 86 & 0.0 & & & & & \\
\hline T. dicoccum 22860 & Ae. squarrosa 29341 & 155 & 19.0 & 30 & 03 & & 00 & \\
\hline T. dicoccum 22861 & Ae. squarrosa 20221-I & 134 & 1.5 & 02 & 01 & & 00 & \\
\hline T. dicoccum 22870 & Ae. squarrosa 20211 & 66 & 3.0 & 02 & 02 & & 00 & \\
\hline \multirow[t]{2}{*}{ T. dicoccum 22870} & Ae. squarrosa 20221-I & 26 & 0.0 & & & & & \\
\hline & & 3,743 & 3.5 & 131 & 44 & $(33.6 \%)$ & 33 & $(75.0 \%)$ \\
\hline TOTAL & & 9,717 & 2.4 & 234 & 94 & $(40.0 \%)$ & 75 & $(79.8 \%)$ \\
\hline
\end{tabular}

*Capital letters mean progeny of one selected plant. **Plants died before or in the beginning of tillering stage.

Table II - Results of crosses between Aegilops squarrosa (DD) and tetraploid species (AABB).

\begin{tabular}{|c|c|c|c|c|c|c|}
\hline $\begin{array}{l}\text { Female parent } \\
(\mathrm{AABB})\end{array}$ & $\begin{array}{l}\text { Male parent } \\
\text { (DD) }\end{array}$ & $\begin{array}{l}\text { Flowers } \\
\text { pollinated }\end{array}$ & $\begin{array}{c}\text { Grains } \\
(\%)\end{array}$ & $\begin{array}{c}\text { Embryos } \\
\text { rescued }\end{array}$ & $\begin{array}{c}\text { Green } \\
\text { plantlets }\end{array}$ & $\begin{array}{c}\text { Fertile } \\
\text { plants recovered }\end{array}$ \\
\hline Ae. squarrosa 20211-C* & T. dicoccum 22860 & 64 & 20,0 & 13 & 03 & 0 \\
\hline Ae. squarrosa 20211-C & T. dicoccum 22870 & 288 & 21,0 & 61 & 05 & 0 \\
\hline Ae. squarrosa 20221-I & T. dicoccum 22860 & 42 & 24,0 & 10 & 00 & \\
\hline Ae. squarrosa 20221-I & T. dicoccum 22870 & 148 & 22,0 & 32 & 13 & 0 \\
\hline Ae. squarrosa 29341 & T. dicoccum 22860 & 136 & 19,0 & 26 & 10 & 0 \\
\hline Ae. squarrosa 29381 & T. dicoccum 22860 & 64 & 16,0 & 10 & 00 & \\
\hline Ae.squarrosa 20211-C & T. durum 22912 & 44 & 4,5 & 02 & 02 & 0 \\
\hline Ae. squarrosa 20221-I & T. durum 22912 & 54 & 7,0 & 04 & 03 & 0 \\
\hline \multirow[t]{2}{*}{ Ae. squarrosa 29341} & T. durum 22912 & 22 & 32,0 & 07 & 02 & 0 \\
\hline & & 862 & (19.1) & 165 & $38 \quad(23.0 \%)$ & $0 \quad(0.0 \%) * *$ \\
\hline
\end{tabular}

*Capital letters mean progeny of one selected plant. **Plants died before or in the beginning of tillering stage. 
Table III - Fertile new synthetic lines obtained from the crosses presented in Table I.

\begin{tabular}{|llc|}
\hline $\begin{array}{l}\text { Line } \\
\text { Number }\end{array}$ & \multicolumn{1}{c}{ Parental cross } & $\begin{array}{c}\text { Cross } \\
\text { number }\end{array}$ \\
\hline PF 804001 & T. durum 22909/ Ae. squarrosa 20229-C & F 23800 \\
PF 804002 & T. durum 22909/ Ae. squarrosa 20229-C & F 23800 \\
PF 834001 & T. durum 22912/ Ae. squarrosa 29342 & F 25992 \\
PF 844001 & T. durum 55559/ Ae. squarrosa 29341 & F 25987 \\
PF 844002 & T. durum 55559/ Ae. squarrosa 29341 & F 25987 \\
PF 844003 & T. durum 55559/ Ae. squarrosa 29341 & F 25987 \\
PF 844004 & T. durum 22912/ Ae. squarrosa 20211-Y & F 25989 \\
PF 844005 & T. durum 22912/ Ae. squarrosa 20211-C & F 25988 \\
PF 844006 & T. durum 22912/ Ae. squarrosa 20221-I & F 25990 \\
PF 844007 & T. durum 22912/ Ae. squarrosa 29341 & F 25991 \\
PF 844008 & T. durum 22912/ Ae. squarrosa 20221-I & F 25990 \\
\hline
\end{tabular}

Consequently, the interaction between phytophatologists, agronomists, and cytogeneticists, similar to what is observed in wheat-exporting countries over the past 60 years, is extremely important for the improvement of bread wheat in South America in the near future.

The artificial resynthesis of hexaploid wheat is impossible to be done by conventional procedures. It is necessary environment-controlled support, cytogenetics and tissue culture techniques but, more critical than everything, it needs interdisciplinary cooperation to obtain useful products for breeding programs. It gives the possibility of obtaining homozygous hexaploid genotypes simultaneously combining useful genes from two species in one step.

The perspectives of molecular cloning-related genes and plant transformation increase the expectations to effectively harness the useful genetic variability identified in related species to improve yield potential and yield sustentability in wheat. The procedures here described certainly will remain basic for future experiments and meanwhile are more suitable for practical breeding.

\section{REFERENCES}

Angra, D.C. (1995). Transferência da resistência à ferrugem da folha através de cruzamentos intergenéricos entre Triticum aestivum e Agropyron elongatum. Dissertação Mestrado, Universidade Federal de Pelotas, Pelotas, RS.

Angra, D.C., Barbosa, M.M., Prestes, A.M. and Moraes-Fernandes, M.I.B. (1999). Cultivo de embriões em retrocruzamentos entre Triticum aestivum Thell. e Agropyron elongatum Host. \& Beauv. Pesqui. Agropecu. Bras. 34: 209-215.

Aragon-Alcaide, L., Miller, T., Schwarzacher, T., Reader, S. and Moore, G. (1996). A cereal centromeric sequence. Chromosoma 105: 261-268.

Aragon-Alcaide, L., Reader, S., Miller, T. and Moore, G. (1997). Centromeric behaviour in wheat with high and low homeologous chromosomal pairing. Chromosoma 106: 327-333.

Barcellos, A.L., Roelfs, A.P. and Moraes-Fernandes, M.I.B. de (2000). Inheritance of adult plant leaf rust resistance in the Brazilian wheat cultivar Toropi. Plant Dis. 84: 90-93.

Barcelo, P., Rasco-Gaunt, S., Sparks, C., Cannell, M., Salgueiro, S., Rooke, L., He, G.Y., Lamacchia, C., De La Viña, G., Shewry, P.R. and Lazzeri, P.A. (1998). Transformation of wheat: State of the technology and examples of application. In: Proceedings of 9 th International
Wheat Genetics Symposium. University of Saskatchewan, Saskatoon, Vol. 1, pp. 143-146.

Bell, G.D.H. (1987). The history of wheat cultivation. In: Wheat Breeding (Lupton, F.G.H., ed.). Chapman and Hall, London, Chapter 2, pp. 31-49.

Blakeslee, A. (1937). Dédoublement du nombre des chromosomes chez les plantes par traitement chimique. C.R. Acad. Sci. Paris 205: 476479.

Blechl, A.E. and Anderson, O.D. (1998). Engineering qualitative and quantitative changes in wheat high-molecular-weight glutenin subunit composition via genetic transformation. In: Proceedings of the 9th International Wheat Genetics Symposium. University of Saskatchewan; Saskatoon, Vol.1., pp. 163-166.

Bowden, W.M. (1959). The taxonomy and nomenclature of the wheats, barley, and ryes and their wild relatives. Can. J. Bot. 37: 657-684.

Brammer, S.P., Worland, A., Barcellos, A.L. and Moraes Fernandes, M.I.B. (1998). Monosomic analysis of adult-plant resistance to leaf rust in the Brazilian wheat cultivar "Toropi". In: Proceedings of 9th International Wheat Genetics Symposium. University of Saskatchewan, Saskatoon, Vol. 2, pp. 17-18.

Bushnell, W.R., Somers, D.A., Giroux, R.W., Szabo, L.J. and Zeien, R.J. (1998). Genetic engineering of disease resistance in cereals. Can. J. Plant Pathol. 20: 137-220.

Caetano, V. da R. (1988). Melhoramento e adaptação ecológica às condições do Rio Grande do Sul. In: Anais do $6^{\circ}$ Encontro de Geneticistas do Rio Grande do Sul. Sociedade Brasileira de Genética Regional Rio Grande do Sul, Porto Alegre, pp. 57-58.

Cauderon, Y. (1981). Hibridation Interspecifique et Amelioration des Plants. I. Evolution des Vois d'Etude des Relations entre Espèces. Académie d'Agriculture de France, Alençon. (Extrait de proces.Verbal de la Seance du 17 juin 1981), pp. 1001-1012.

Chibbar, R.N., Baga, M., Caswell, K., Repellin, A., Leung, N., Abdel, A. and Hucl, P. (1998). Genetic transformation strategies to alter starch structure in wheat. In: Proceedings of the 9th International Wheat Genetics Symposium. University of Saskatchewan; Saskatoon, Vol. 1., pp. $167-170$.

Darlington, C.D. (1973). Chromosome Botany and the Origin of Cultivated Plants. G. Allen \& Unwin, Londres.

Day, P.R. and Lupton, F.G.H. (1987). Future prospects. In: Wheat Breeding (Lupton, F.G.H., ed.). Chapman and Hall, London, Chapter 17, pp. 539552

Dhalival, H.S., Gill, K.S., Singh, P.J., Multani, D.S. and Singh, B. (1986). Evaluation of germplasm of wild wheats, Aegilops and Agropyron for resistance to various diseases. Crop Improv. 13: 107-112.

Dvorak, J. (1972). Genetic variability in Aegilops speltoides affecting homeologous pairing in wheat. Can. J. Genet. Cytol. 14:371-380.

Dvorak, J. (1998). Genome analysis in the Triticum Aegilops alliance. In: Proceedings of 9th International Wheat Genetics Symposium. University of Saskatchewan, Saskatoon, Vol. 1, pp. 8-11.

Fedak, G. (1998). Procedures for transferring agronomic traits from alien species to crops plants. In: Proceedings of 9th International Wheat Genetics Symposium. University of Saskatchewan, Saskatoon, Vol. 1, pp. 1-7.

Feldmann, M. (1976). Wheats, Triticum ssp. (Gramineae Triticineae). In: Evolution of Crop Plants (Simmonds, N.W., ed.). Longmam, London, pp. 120-128.

Feldmann, M. (1977). Historical aspects and significance of the discovery of wild wheats. In: Proceedings of the 9th Stadler Genetics Symposium. Inst., Columbia, pp. 121-145.

Flavell, R.B., Bennett, M.D., Seal, A.G. and Hutchinson, J. (1987). Chromosome structure and organization. In: Wheat Breeding (Lupton, F.G.H., ed.). Chapman and Hall, London, Chapter 8, pp. 211-268.

Fry, J.E., Cheng, M., Hu, T., Layton, J., Wan, Y., Zhou, H., Duncan, D.R., Hironaka, C., Pang, S., Liang, J. and Conner, T. (1998). Advances in the genetic engineering of wheat. In: Proceedings of 9th International Wheat Genetics Symposium. University of Saskatchewan, Saskatoon, Vol. 1, pp. 156-158.

Gale, M.D. and Miller, T.E. (1987). The introduction of alien genetic variation into wheat. In: Wheat Breeding (Lupton, F.G.H., ed.). Chapman and Hall, London, Chapter 7, pp. 173-210.

Gill, B.S. and Gill, K.S. (1998). Molecular cytogenetic exploration into the genome of wheat. In: Proceedings of 9th International Wheat Genet- 
ics Symposium. University of Saskatchewan, Saskatoon, Vol. 1, pp. 29-32.

Gouvea, P.M., Brammer, S.P., Angra, D.C., Prestes, A.M. and MoraesFernandes, M.I.B. (1997). Análise molecular em haplóides obtidos a partir de híbridos intergenéricos entre Triticum aestivum e Agropyron elongatum. In: Programas e Resumos do $2^{\circ}$ Encontro Brasileiro de Biotecnologia Vegetal. REDBIO - Sub-Região Brasil, Gramado, pp. 221.

Gregory, R.S. (1987). Triticale breeding. In: Wheat Breeding (Lupton, F.G.H., ed.). Chapman and Hall, London, Chapter 9, pp. 269-286.

Harvey, T.L., Martin, T.J. and Livers, R.W. (1980). Resistance to biotype C. greenburg in synthetic hexaploid wheats derived from Triticum tauschii. J. Econ. Entomol. 3: 387-389.

Higgins, V.J., Iu, H., Xing, T., Gelli, A. and Blunwald, E. (1998). The genefor-gene concept and beyond: interactions and signals. Can. J. Plant Pathol. 20: 150-157.

Jenkins, B.C. and Mochizuki, A. (1957). A new amphiploid from a cross between Triticum durum and Agropyron elongatum $(2 \mathrm{n}=14)$. Wheat Inf. Serv. 5: 15 .

Kasha, K.J., Hu, T.C., Simion, E. and Oro, R. (1998). Cytological development of wheat microspores in culture. In: Proceedings of 9th International Wheat Genetics Symposium. University of Saskatchewan, Saskatoon, Vol. 1, pp. 1152-1155.

Kerber, E.R. and Dyck, P.L. (1969). Inheritance in hexaploid wheat of leaf rust resistance and other characters derived from Aegilops squarrosa. Can. J. Genet. Cytol. 11: 639-647.

Kerber, E.R. and Dyck, P.L. (1973). Inheritance of stem rust resistance transferred from diploid wheat (Triticum monococcum) to tetraploid and hexaploid wheat and chromosome location of the gene envolved. Can. J. Genet. Cytol. 15: 397-409.

Kerber, E.R. and Green, G.J. (1980). Suppression of stem rust resistance in the hexaploid wheat by chromosome 7DL. Can J. Bot. 58: 13471350

Kimber, G. (1977). The use of aneuploids in studies of genetics, breeding and evolution in wheat. In: Proceedings of the International Simposium in Genetic Diversity in Plants, pp. 103-116.

Knott, D.R. (1961). The inheritance of rust resistance.VI the transfer of stem rust resistance from Agropyron elongatum to common wheat. Can. J. Plant Sci. 41: 109-123.

Knott, D.R. (1989). The Origin and Evolution of Wheat. In: The Wheat Rusts - Breeding for Resistance. Monographs on Theoretical and Applied Genetics. Springer-Verlag, Berlin, pp. 1-6.

Knott, D.R. and Dvorak, J. (1976). Alien germplasm as a source of resistance to diseases. Annu. Rev. Phytopathol. 14: 211-235.

Lagos, M.B., Moraes Fernandes, M.I.B. de, Camargo, C.E. de O., Federizzi, L.C. and Carvalho, F.I.F. (1991). Genetics and monosomic analysis of aluminum tolerance in wheat (Triticum aestivum L.). Rev. Bras. Genet. 14: 1011-1020

Law, C.N., Snape, J.W. and Worland, A.J. (1987). Aneuploidy in wheat and its uses in genetic analysis. In: Wheat Breeding (Lupton, F.G.H., ed.). Chapman and Hall, London, Chapter 4, pp. 71-108.

Lewis, K.R. and John, B. (1965). Cycles, systems and sex. In: The Matter of Mendelian Heredity. John Willey \& Sons, New York, Chapter 4, pp. 93-130.

Lilienfeld, F.A. (1951). H. Kihara: Genome-analysis in Triticum and Aegilops. Concluding review. Cytologia 16: 101-123.

Luz, W.C. (1984). Yield losses caused by Fungal Foliar wheat pathogens in Brasil. Phytopathology 74: 1403-1407.

MacKey, J. (1970). Significance of mating systems for chromosomes and gametes in polyploids. Hereditas 66: 165-176.

MacKey, J. (1987). Plant Breeding Aspects on Taxonomy of Cultivates Plants. Swedish University Agricultural Sciences, Uppsala. Invited paper read at 14th International Botanical Congress, Berlin.

McFadden, E.S. and Sears, E.R. (1944). The artificial synthesis of Triticum spelta. Rec. Genet. Soc. Am. 13:26-27.

McFadden, E.S. and Sears, E.R. (1946). The origin of Triticum spelta and its free-threshing hexaploid relatives. J. Hered. 37: 81-89, 107-116.

Miller, T.E. (1987). Systematics and evolution. In: Wheat Breeding (Lupton, F.G.H., ed.). Chapman and Hall, London, Chapter 1, pp. 1-30.

Miller, T.E., Reader, S.M., Shau, P.J. and Moore, G. (1998). Towards an understanding of the $P h 1$ locus in wheat. In: Proceedings of 9th
International Wheat Genetics Symposium. University of Saskatchewan, Saskatoon, Vol. 1, pp.17-19.

Moraes-Fernandes, M.I.B. de, Fernandes, J.M.C., Picinini, E.C., Aita, L. and Sartori, J.F. (1980). Transferência de genes de resistência a Septoria nodorum (Berk). Berk. de espécies afins para o trigo. In: Resumos e Comunicados Técnicos da 11 Reunião Nacional de Pesquisa de Trigo. EMBRAPA-CNPT, Passo Fundo, pp. 139-140.

Moraes-Fernandes, M.I.B. de, Barcellos, A.L., Caetano, V.R., Coelho, E.T. Kerber, E., Linhares, W.I., Prestes, A.M. and Zanatta, A.C. (1988). O uso de espécies afins ao trigo como fontes de resistência a moléstias fúngicas. In: Resumos da 15 Reunião Nacional de Pesquisa de Trigo. EMBRAPA-CNPT, Passo Fundo, pp. 126.

Moraes-Fernandes, M.I.B. de, Antoniolli, S.R., Barcelos, A.L., Coelho, E.T. and Linhares, W.I. (1990). Transferência de genes de resistência a moléstias fúngicas (ferrugem e oídio) de espécies afins para o trigo cultivado Triticum aestivum L. Thell através do cultivo de embriões híbridos. Cienc. Cult. 42: 474-475.

Moraes-Fernandes, M.I.B. de, Caetano, V.R., Kerber, E. and Picard, E. (1991). Cytogenetics and biotechnology to accelerate wheat breeding in Southern Brazil: production of synthetic hexaploids from related species and doubled haploids from anther culture. In: Wheat for the Nontraditional Warm Areas (Saunders, D.A., ed.). UNDP/CIMMYT, Mexico, pp. 530-536.

Moraes-Fernandes, M.I.B. de, Stival, A.L., Brammer, S.P. and Grando, M.F. (1999). Haplodiploidização: genética e melhoramento. In: Cultura de Tecidos e Transformação Genética de Plantas (Torres, A.C., Caldas, L.S. and Buso, J.A., eds.). Embrapa Serviço de Produção e Informação/ Embrapa Hortaliças, Brasília, Vol. 2, pp. 612-650.

Morris, R. and Sears, E.R. (1967). The cytogenetics of wheat and its relatives. In: Wheat and Wheat Improvement (Quisenberry, K.S. and Reitz, L.P., eds.). American Society of Agronomy, Madison, pp. 19-87.

Peters, J.A., Bobrowski, V.L. and Rosinha, G.M.S. (1999). Produção de haplóides e duplo-haplóides. In: Cultura de Tecidos e Transformação Genética de Plantas (Torres, A.C., Caldas, L.S. and Buso, J.A., eds.). Embrapa Serviço de Produção e Informação/Embrapa Hortaliças, Brasília, Vol. 2, pp. 569-611.

Peterson, R.F. (1965). Wheat Botany, Cultivation and Utilization. Interscience, New York.

Picard, E., Crambes, E. and Mihamou-Ziyyat, A. (1994). Évolution des méthodes d'haploidisation et perspectives pour l'ámélioration des plantes. C.R. Seances Soc. Biol. Paris 188: 109-141.

Picinini, E.C., Fernandes, J.M. and Ignaczak, J.C. (1993). Effect of propiconazole spraying on yields of wheat and barley in southern Brasil during 1981 to 1992. In: Abstracts of the 6th International Congress of Plant Pathology. Canadian Phytopathological Society, Montreal, pp. 53.

PoehIman, J.M. and Sleper, D.A. (1996). Breeding wheat. In: Breeding Field Crops (Poehlman, J.M. and Sleper, D.A., eds.). Iowa State University Press, Ames, Chapter 14., pp. 259-277.

Prestes, A.M., Angra, D.M., Barbosa, M.M. and Moraes-Fernandes, M.I.B. (1994). Fontes de resistência a Stagonospora nodorum em Aegilops squarrosa, espécies afim ao trigo cultivado. Fitopatol. Bras. 19: 510513

Reide, C.R. and Anderson, J.A. (1996). Linkage of RFLP markers to an aluminum tolerance gene in wheat. Crop Sci. 36: 905-909.

Riley, R. (1965). Cytogenetics and the evolution of wheat. In: Crop Plant Evolution (Hutchinson, J., ed.). Cambridge University Press, London, pp. 103-108.

Riley, R. and Kimber, G. (1966). The transfer of alien genetic variation to wheat. Annu. Rep. Plant Breed. Inst. 1964-1965, pp. 6-36.

Riley, R. and Law, C.N. (1965). Genetic variation in chromosome pairing. Adv. Genet. 13: 57-114.

Riley, R., Chapman, V. and Kimber, G. (1958). Genetic control of the cytologically diploid behaviour of hexaploid wheat. Nature 182: 713-715.

Riley, R., Chapman, V. and Kimber, G. (1959). Genetics control of chromosome pairing in intergeneric hybrid with wheat. Nature 183: 12441246.

Riley, R., Chapman, V. and Johnson, R. (1968). Introduction of yellow rust resistance of Ae. comosa in wheat by genetically induced homoeologous recombination. Nature 217: 383-387.

Sarkar, P. and Stebbins, G.L. (1956). Morphological evidence concerning 
the origin of the B genome in wheat. Am. J. Bot. 43: 297-304.

Sears, E.R. (1939). Cytogenetic studies with polyploid species of wheat. I. Chromosomal aberrations in the progeny of a haploid of Triticum vulgare. Genetics 124: 509-523.

Sears, E.R. (1944). Cytogenetic studies with polyploid species of wheat. II. Additional chromosomal aberrations in Triticum vulgare. Genetics 29: $232-246$.

Sears, E.R. (1954). The Aneuploids of Common Wheat. University of Missouri, Columbia.

Sears, E.R. (1956). The transfer of leaf rust resistance frow Aegilops umbellulata to wheat. In: Proceedings of the 9th Brookhaven Symposia in Biology. Genet. Plant Breed. 9: 1-22.

Sears, E.R. (1958). The aneuploids of common wheat. In: Proceedings of the 1st International Wheat Genetics Symposium. University of Manitoba, Winnipeg, pp. 221-228.

Sears, E.R. (1965). Transfer of genes from wild relatives to wheat. Genetics 1: 107-120.

Sears, E.R. (1966). Nullisomic-tetrasomic combination in hexaploid wheat. In: Chromosome Manipulation and Plant Genetics (Riley, R. and Lewis, K.R., eds.). Oliver \& Boyd, Edinburg, pp. 39-45.
Sears, E.R. (1972). Chromosome engineering in wheat. In: Proceedings of the 4th Stadler Symposia. University of Missouri, Columbia, pp. 23-28.

Sears, E.R. and Okamoto, M. (1958). Intergenomic relationship in hexaploid wheat. In: Proceedings of the 1st International Congress of Genetics. University of Manitoba, Winnipeg, Vol. 12, pp. 258-259.

Sharma, D. and Knott, D.R. (1966). The transfer of leaf-rust resistance frow Agropyron to Triticum by irradiation. Can. J. Genet. Cytol. 8: 137-143.

Snape, J.W. (1987). Conventional methods of genetic analysis in wheat. In: Wheat Breeding (Lupton, F.G.H., ed.). Chapman and Hall, London, Chapter 2, pp. 31-49.

Stalker, H.T. (1980). Utilization of wild species for crop improvement. $A d v$. Agron. 33: 111-147.

Worland, A.J., Gale, M.D. and Law, C.N. (1987). Wheat genetics. In: Wheat Breeding (Lupton, F.G.H., ed.). Chapman and Hall, London, Chapter 6, pp. 129-172.

Yan, L., Fairclough, R. and Bhave, M. (1998). Molecular evidence supporting the origin of the B genome of Triticum turgidum from T. speltoides. In: Proceedings of 9th International Wheat Genetics Symposium. University of Saskatchewan, Saskatoon, Vol. 2, pp. 119-121. 